\title{
Symmetrical $\alpha$-bromoacryloylamido diaryldienone derivatives as a novel series of antiproliferative agents. Design, synthesis and biological evaluation
}

\author{
Romeo Romagnoli ${ }^{\mathrm{a}, *}$, Pier Giovanni Baraldi ${ }^{\mathrm{a}, *}$, Olga Cruz-Lopez ${ }^{\mathrm{a}}$, Carlota Lopez Cara ${ }^{\mathrm{a}}$, Maria Dora Carrion ${ }^{\mathrm{a}}$, \\ Jan Balzarini ${ }^{\mathrm{b}}$, Ernest Hamel ${ }^{\mathrm{c}}$, Giuseppe Basso ${ }^{\mathrm{d}}$, Roberta Bortolozzi ${ }^{\mathrm{d}}$, Giampietro Viola ${ }^{\mathrm{d}}$ \\ a Dipartimento di Scienze Farmaceutiche, Università di Ferrara, 44100 Ferrara, Italy \\ ${ }^{\mathrm{b}}$ Rega Institute for Medical Research, Laboratory of Virology and Chemotherapy, B-3000 Leuven, Belgium \\ c Screening Technologies Branch, Developmental Therapeutics Program, Division of Cancer Treatment and Diagnosis, National Cancer Institute at Frederick, \\ National Institutes of Health, Frederick, 21702 MD, USA \\ ${ }^{\mathrm{d}}$ Dipartimento di Pediatria, Laboratorio di Oncoematologia, Università di Padova, 35131 Padova, Italy
}

\section{A R T I C L E I N F O}

\section{Article history:}

Received 9 January 2010

Revised 17 March 2010

Accepted 19 March 2010

Available online 25 March 2010

\section{Keywords:}

Antiproliferative activity

Apoptosis

Antitumor agents

Hybrid compounds

\begin{abstract}
A B S T R A C T
In a continuing study of hybrid compounds containing the $\alpha$-bromoacryloyl moiety as potential anticancer drugs, we synthesized a novel series of hybrids $\mathbf{4 a - h}$, in which this moiety was linked to a 1,5-diaryl-1,4pentadien-3-one system. Many of the conjugates prepared (4b, $\mathbf{4 c}, \mathbf{4 e}$ and $\mathbf{4 g}$ ) demonstrated pronounced, submicromolar antiproliferative activity against four cancer cell lines. Moreover, compound $4 \mathrm{~b}$ induced apoptosis through the mitochondrial pathway and activated caspase- 3 in a concentration-dependent manner.
\end{abstract}

(c) 2010 Elsevier Ltd. All rights reserved.
Because of their ability to interact with cellular nucleophiles, Michael acceptors are often employed as a powerful tool in the design of anticancer agents. ${ }^{1}$ The $\alpha, \beta$-unsaturated carbonyl group is capable of undergoing Michael addition, and this moiety may be highly deleterious for malignant cells because it could interfere at multiple points in biological cascades through successive attacks on cellular nucleophiles. ${ }^{2}$ Among the $\alpha, \beta$-unsaturated ketones, enones and dienones derivatives, the chalcones ${ }^{3}$ and the $\alpha, \alpha^{\prime}$-bis(arylidene)ketones, ${ }^{4-7}$ are versatile pharmacophores belonging to the class of Michael acceptors. In previous studies, the 1,5-diaryl-3-oxo-1,4-pentadienyl system was incorporated into various cyclic and acyclic scaffolds with general formula 1a and $\mathbf{1 b}$, and these compounds included derivatives that demonstrated promising antiproliferative activities against cancer cell lines. ${ }^{4,8}$ The aromatic symmetrical dienones $\mathbf{1 a}$ and $\mathbf{1 b}$ act as $\mathrm{Mi}$ chael acceptors, suggesting that two successive alkylations of the $\beta$-positions of the reactive dienone system by cellular thiols could be one mechanism by which these compounds exert their antiproliferative activity in vitro. ${ }^{9-12}$

The $\alpha$-bromoacryloyl alkylating moiety is present in a series of potent anticancer distamycin-like minor groove binders, including

\footnotetext{
* Corresponding authors. Tel.: +39 532 455303; fax: +39 532455953 (R.R.); tel. +39532 291293; fax: +39532455953 (P.G.B.)

E-mail addresses: rmr@unife.it (R. Romagnoli), baraldi@unife.it (P.G. Baraldi).
}

PNU-166196 (brostallicin), which is currently undergoing Phase II clinical trials as a first-line single agent chemotherapy in patients with advanced or metastatic soft tissue sarcoma (Chart 1$).{ }^{13}$ It has been hypothesized that the reactivity of the $\alpha$-bromoacryoyl moiety results from a first-step Michael-type nucleophilic attack, followed by a further reaction of the former vinylic bromo substituent alpha to the carbonyl, leading successively either to a second nucleophilic substitution or to a beta elimination. ${ }^{14}$

In a recent publication, we reported a series of $\alpha$-bromoacryloylamido chalcones with general structure 2 , containing a pair of Michael acceptors in their structure, corresponding to the $\alpha$-bromoacryloyl moiety and the $\alpha, \beta$-unsaturated ketone system of the chalcone framework. ${ }^{15}$ Electron-releasing and electronwithdrawing groups on the phenyl linked to the carbonyl significantly influenced the antiproliferative activity. Of the tested compounds, derivative $\mathbf{2 a}(4-\mathrm{Br})$ and $\mathbf{2 b}(4-\mathrm{OMe})$ displayed $\mathrm{IC}_{50}$ values of $0.62-1.1$ and $0.98-1.4 \mu \mathrm{M}$, respectively, against a panel of four cancer cell lines (Table 1 ).

The conversion of $\boldsymbol{\alpha}$-bromoacryloylamido chalcones 2ab into the corresponding unsymmetrical dienones $\mathbf{3 a b}$ led to a reduction in activity $(0.62-1.1 \mu \mathrm{M}$ for $2 \mathrm{a}$ vs $8.3-40 \mu \mathrm{M}$ for $\mathbf{3 a}, 0.98-1.4 \mu \mathrm{M}$ for $\mathbf{2 b}$ vs $2.2-6.5 \mu \mathrm{M}$ for $\mathbf{3 a}){ }^{16}$

The observations that both the 1,5-diaryl-3-oxo-1,4-pentadienyl and the $\alpha$-bromoacryloyl groups can act as trapping agents of cellular nucleophiles led us to prepare and evaluate a novel class 
<smiles>O=C(/C=C/c1[R]ccc1)/C=C/c1ccccc1</smiles>

1a<smiles></smiles>

1b

$\mathrm{R}=$ electron-releasing or electron-withdrawing groups $\mathrm{X}=\mathrm{NH}, \mathrm{N}$-alkyl or $\mathrm{N}$-alkoxycarbonyl $\mathrm{X}=\left(\mathrm{CH}_{2}\right) \mathrm{n}$ with $\mathrm{n}$ from 0 to 4 .<smiles>C=C(Br)C(=O)Nc1cc(C(C)C)n(C)c1C(=O)NCCNC(N)Cl</smiles>

PNU-166196 or Brostallicin<smiles>C=C(Br)C(=O)Nc1ccc(/C=C/C(=O)c2ccccc2)cc1</smiles>

$\mathrm{R}=\mathrm{H}$, OMe, Me, $\mathrm{N}\left(\mathrm{CH}_{3}\right)_{2}$, halogen $\mathrm{R}=4-\mathrm{Br}, 2 \mathrm{a}$ $\mathrm{R}=4-\mathrm{OMe}, 2 \mathrm{~b}$<smiles>C=C(Br)C(=O)Nc1cccc(/C=C/C(=O)/C=C/c2cccc(NC(=O)C(=C)Br)c2)c1</smiles><smiles>C=C(Br)C(=O)Nc1ccc(/C=C/C(=O)/C=C/c2ccc(P)cc2)cc1</smiles>

$\mathrm{R}=4-\mathrm{Br}, \mathbf{3 a}$ $\mathrm{R}=4-\mathrm{OMe}, 3 \mathrm{~b}$

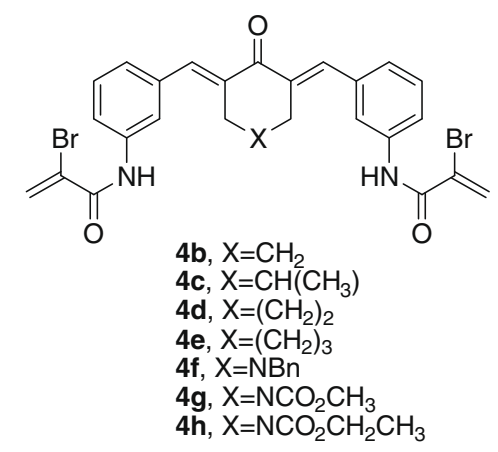

Chart 1.

of synthetic conjugates with general formulae 4, incorporating these two moieties within their structures (Chart 1 ). If such processes occur, the bis-( $\alpha$-bromoacryloylamidoarylidene) ketone derivatives $\mathbf{4 a}-\mathbf{h}$, characterized by the presence of four potential sites for electrophilic attack on cellular constituents, should be more active than the corresponding 1,5-diaryl-1,4-pentadien-3one system, containing only two nucleophilic centers.

In particular, we have synthesized three different small series of bis-( $\alpha$-bromoacryloylamidoarylidene) ketone derivatives, corresponding to the acyclic analogue $\mathbf{4 a}$, the cyclic conjugates $\mathbf{4 c - e}$, and finally the 4-piperidone derivatives $\mathbf{4 f}-\mathbf{h}$.

The three different series of cyclic ketones $\mathbf{4 b}$ and $\mathbf{4 d e}$ were prepared with the aim of evaluating how the size of the ring influenced antiproliferative activity. By the synthesis of compound $\mathbf{4 c}$, we evaluated the effect of the introduction of a small hydrophobic substituent, corresponding to a methyl group, at the 4-position of the cyclohexanone ring.

Hybrid compounds $\mathbf{4 a - h}$ were prepared by the procedure described in Scheme 1. The Claisen-Schmidt aldol condensation ${ }^{17}$ between 3-nitrobenzaldehyde or 4-nitrobenzaldehyde with the appropriate commercially available acetone, cyclic ketone or $\mathrm{N}$ - substituted 4-piperidone in the presence of lithium hydroxide monohydrate as base in ethanol led to the formation of the corresponding $\alpha, \alpha$-bis (3-nitrobenzylidene)ketones $\mathbf{5 a - h}$ or (1E,4E)-1,5-bis(4-nitrophenyl)penta-1,4-dien-3-one $\mathbf{5 i}$ in $65-73 \%$ yields. $\alpha, \alpha$-Bis-(aminobenzylidene) ketones $6 \mathbf{a}-\mathbf{i}$ were generated from the corresponding nitro derivatives $\mathbf{5 a - i}$ by reduction with iron and ammonium chloride in a refluxing mixture of water and ethanol $(1: 4 \mathrm{v} / \mathrm{v})$.

Finally, the hybrid compounds $\mathbf{4 a - k}$ were prepared in $50-62 \%$ yields by the condensation of $\alpha$-bromoacrylic acid with bis-(3-anilinomethylidene) ketones $\mathbf{6 a}-\mathbf{h}$, respectively. This condensation was performed using an excess (4 equiv) of both 1-ethyl-3-[3(dimethylamino)propyl]carbodiimide hydrochloride (EDCl) and 1-hydroxy-1,2,3-benzotriazole (1-HOBt) in dry DMF as solvent at room temperature and with identical reaction times ( $18 \mathrm{~h})$.

Table 1 summarizes the inhibitory effects of bis-( $\alpha$-bromoacryloylamido arylidene) ketone derivatives $\mathbf{4 a - h}$ on the proliferation of murine leukemia (L1210), murine mammary carcinoma (FM3A), human T-leukemia (CEM) and human cervix carcinoma (HeLa) cells, with bis-(aminobenzylidene)ketones 6a-i, $\boldsymbol{\alpha}$-bromoacryloylamido chalcones 2ab and $\alpha$-bromoacryloylamido bis-(arylidene)ketones 
Table 1

In vitro inhibitory effects of compounds $\mathbf{2} \mathbf{a b}, \mathbf{3 a b}, \mathbf{4 a}-\mathbf{h}$ and $\mathbf{6 a}-\mathbf{i}$ on the proliferation of murine leukemia (L1210), murine mammary carcinoma (FM3A), human Tleukemia (CEM) and human cervix carcinoma (HeLa) cells

\begin{tabular}{lcccc}
\hline \multirow{2}{*}{ Compound } & \multicolumn{4}{c}{$\mathrm{IC}_{50}{ }^{\mathrm{a}}(\mu \mathrm{M})$} \\
\cline { 2 - 5 } & $\mathrm{L} 1210$ & $\mathrm{FM} 3 \mathrm{~A}$ & $\mathrm{CEM}$ & $\mathrm{HeLa}$ \\
\hline $\mathbf{2 a}$ & $0.62 \pm 0.20$ & $1.1 \pm 0.8$ & $0.99 \pm 0.31$ & $1.0 \pm 0.0$ \\
$\mathbf{2 b}$ & $0.98 \pm 0.96$ & $1.2 \pm 0.5$ & $1.4 \pm 1.2$ & $1.4 \pm 0.2$ \\
$\mathbf{3 a}$ & $9.3 \pm 6.9$ & $40 \pm 8$ & $11 \pm 4$ & $8.3 \pm 0.2$ \\
$\mathbf{3 b}$ & $2.4 \pm 1.6$ & $2.2 \pm 0.5$ & $6.5 \pm 0.5$ & $4.4 \pm 4.3$ \\
$\mathbf{6 a}$ & $7.8 \pm 0.7$ & $9.2 \pm 0.7$ & $6.1 \pm 0.9$ & $4.8 \pm 4.4$ \\
$\mathbf{6 b}$ & $6.9 \pm 0.5$ & $9.1 \pm 0.7$ & $1.7 \pm 0.1$ & $5.2 \pm 3.4$ \\
$\mathbf{6 c}$ & $4.8 \pm 1.0$ & $8.9 \pm 0.8$ & $1.6 \pm 0.1$ & $1.8 \pm 0.5$ \\
$\mathbf{6 d}$ & $35 \pm 2$ & $42 \pm 0$ & $11 \pm 2$ & $30 \pm 17$ \\
$\mathbf{6 e}$ & $18 \pm 7$ & $29 \pm 9$ & $8.5 \pm 1.9$ & $10 \pm 5$ \\
$\mathbf{6 f}$ & $6.8 \pm 1.0$ & $9.5 \pm 1.4$ & $1.9 \pm 0.2$ & $5.2 \pm 4.7$ \\
$\mathbf{6 g}$ & $9.7 \pm 0.6$ & $18 \pm 6$ & $1.7 \pm 0.1$ & $7.6 \pm 2.0$ \\
$\mathbf{6 h}$ & $9.0 \pm 0.0$ & $17 \pm 5$ & $1.7 \pm 0.05$ & $8.5 \pm 0.1$ \\
$\mathbf{6 i}$ & $60 \pm 14$ & $207 \pm 6$ & $168 \pm 16$ & $107 \pm 91$ \\
$\mathbf{4 a}$ & $4.1 \pm 3.4$ & $6.5 \pm 4.1$ & $2.5 \pm 0.9$ & $4.6 \pm 4.4$ \\
$\mathbf{4 b}$ & $0.32 \pm 0.01$ & $0.47 \pm 0.10$ & $0.30 \pm 0.01$ & $0.70 \pm 0.60$ \\
$\mathbf{4 c}$ & $0.32 \pm 0.03$ & $0.48 \pm 0.02$ & $0.41 \pm 0.09$ & $0.30 \pm 0.02$ \\
$\mathbf{4 d}$ & $1.7 \pm 1.0$ & $1.7 \pm 1.1$ & $1.0 \pm 2.0$ & $4.3 \pm 3.7$ \\
$\mathbf{4 e}$ & $0.38 \pm 0.06$ & $0.73 \pm 0.00$ & $0.34 \pm 0.04$ & $0.35 \pm 0.02$ \\
$\mathbf{4 f}$ & $1.6 \pm 0.7$ & $5.4 \pm 1.2$ & $1.6 \pm 0.0$ & $0.73 \pm 0.63$ \\
$\mathbf{4 g}$ & $0.39 \pm 0.02$ & $0.79 \pm 0.30$ & $0.47 \pm 0.17$ & $0.84 \pm 0.74$ \\
$\mathbf{4 h}$ & $0.62 \pm 0.42$ & $1.1 \pm 0.9$ & $1.4 \pm 0.2$ & $1.6 \pm 0.0$ \\
Melphalan ${ }^{\mathrm{b}}$ & $2.13 \pm 0.03$ & $\mathrm{n} . \mathrm{d}$ & $2.47 \pm 0.30$ & $\mathrm{n} . \mathrm{d}$ \\
\hline
\end{tabular}

n.d. not determined.

${ }^{2} \mathrm{IC}_{50}=$ compound concentration required to inhibit tumor cell proliferation by $50 \%$. Data are expressed as the mean \pm SE from the dose-response curves of at least three independent experiments.

b These data were previously reported in Ref. 7.

3ab as reference compounds. The alkylating agent melphalan was used as a reference drug.

Compounds $\mathbf{6 a}$ and $\mathbf{6 i}$ were synthesized in order to evaluate the influence of the position of amino group on the benzylidene moiety on antiproliferative activity. Changing the location of the amino group from the para- in $\mathbf{6 i}$ to the meta-position as in $\mathbf{6 a}$, led to a 10-25-fold increase in antiproliferative activity against all four cancer cell lines. The higher inhibition of cell growth showed by 6a led us to synthesize $\alpha, \alpha^{\prime}$-bis-(meta-aminobenzylidene) ketone derivatives $\mathbf{6 b}-\mathbf{h}$.

Comparing the activities of $\mathbf{4 a - h}$ with those of $\mathbf{6 a - h}$ demonstrates that insertion of the two $\alpha$-bromoacryloyl moieties was an important molecular change leading to a significant increase in antiproliferative activity. The bis- $(\alpha$-bromoacryloylamido benzylidene) ketones $\mathbf{4 a - h}$ were from 2 - to 50 -fold more active than the corresponding bis-(anilinomethylidene) precursors $\mathbf{6 a - h}$. These values are greater or equal to those obtained with the $\alpha$ bromoacryloylamido enones $\mathbf{2 a b}$. The greater activity of $\mathbf{4 b c}, \mathbf{4 e}$ and $\mathbf{4 g h}$ compared to that of 3ad indicated the contribution of a second $\alpha$-bromoacryloyl moiety to antiproliferative activity.

The compounds displaying the greatest potency were $\mathbf{4 b}, \mathbf{4 c}$ and $4 \mathrm{~g}$, with $\mathrm{IC}_{50}$ values of $0.32-0.38,0.47-0.79,0.30-0.47$ and 0.30 $0.84 \mu \mathrm{M}$ against the L1210, FM3A, CEM and HeLa cell lines, respectively. Notably, the acyclic derivative $4 a$ was significantly less active than its cyclic counterparts $\mathbf{4 b} \mathbf{b} \mathbf{h}$. Derivatives $\mathbf{4 b} \mathbf{b}-\mathbf{h}$ were found to have greatest potency to melphalan against tested cancer cell lines.

In the series of compounds $\mathbf{4 b}-\mathbf{b}$, activity decreased when the size of the cyclic ketone was increased from six to seven carbon units, while it increased greatly when the size of the ring increased from seven to eight carbons (compounds $\mathbf{4 b}$, $\mathbf{4 d}$ and $\mathbf{4 e}$, respectively). Starting from $\mathbf{4 b}$, the 4 -methyl substitution on the cyclohexanone ring, to furnish $\mathbf{4 c}$, did not improve antiproliferative activity against L1210, FM3A and CEM cells, but the methyl group doubled potency with respect to HeLa cells.
Comparing the 4-piperidone derivatives $\mathbf{4 f - h}$, lengthening the alkoxy carbonyl group from methyl to ethyl (compounds $\mathbf{4 g}$ and 4h, respectively) halved antiproliferative activity.

The more basic $N$-benzyl derivative $\mathbf{4 f}$ showed reduced potency relative to $\mathbf{4 g}$ and $\mathbf{4 h}$ against L1210, FM3A and CEM cells, but $\mathbf{4 g}$ and $\mathbf{4 h}$ were equipotent against HeLa cells.

Next, we examined the effects of increasing concentrations of compounds $\mathbf{4 b c}, \mathbf{4 e}$ and $\mathbf{4 g}$ on cell-cycle progression by performing a flow cytometric analysis on HeLa cells (Table 2). Cells were cultured for $24 \mathrm{~h}$ in the absence or presence of each compound at $0.25,0.5$ or $1 \mu \mathrm{M}$, and the cells were stained with propidium iodide (PI). Treatment with $\mathbf{4 b}, \mathbf{4 c}$ or $\mathbf{4 e}$ at $1 \mu \mathrm{M}$ for $24 \mathrm{~h}$ induced a major shift from the G1 to the G2-M phase compared with control cells, but no concentration, of those tested, of compound $\mathbf{4 g}$ altered cell cycle progression. In particular, as shown in Table 2, treatment with $0.25,0.5$ and $1 \mu \mathrm{M}$ of compound $4 \mathbf{b}$ for $24 \mathrm{~h}$ led to a dosedependent decrease of the G1 peak and a proportional accumulation of cells in the G2-M phase, accompanied by a concomitant increase in the population of apoptotic cells, as demonstrated by the increase of the sub-G1 peak. Similar effects on the cell cycle progression were observed with $\mathbf{4 b c}, \mathbf{4 e}$ or $\mathbf{4 g}$ after $48 \mathrm{~h}$ of treatment (see Table 1 in the Supplementary data section).

The induction of apoptosis in HeLa cells was confirmed by the annexin-V test ${ }^{18}$ with compounds $\mathbf{4 b c}, \mathbf{4 e}$ and $\mathbf{4 g}$ at various concentrations for 24 or $48 \mathrm{~h}$. Figure 1 shows a time and concentration-dependent increase of the percentage of annexin- $V$ positive cells for all the tested compounds. Only a small percentage (2-5\%) of necrotic cells was observed with all compounds and only at the highest concentration employed (data not shown).

Since many compounds that arrest the cell cycle at the G2-M phase are tubulin inhibitors, ${ }^{19}$ compounds $\mathbf{4 b c}, \mathbf{4 e}$ and $\mathbf{4 g}$ were evaluated for their inhibitory effects on tubulin polymerization. None of tested compounds were effective as inhibitors of tubulin assembly $\left(\mathrm{IC}_{50}>40 \mu \mathrm{M}\right)$. These data make it unlikely that the antiproliferative activity of these hybrid compounds results from a direct interaction with tubulin and that they act as microtubule depolymerizing agents.

Impairment of mitochondrial function is an early event in the executory phase of programmed cell death in different cell types, and it occurs as a consequence of a preliminary reduction of the mitochondrial transmembrane potential $\left(\Delta \psi_{\mathrm{mt}}\right) .^{20,21}$ Early $\Delta \psi_{\mathrm{mt}}$ disruption results from an opening of mitochondrial permeability transition pores, and this permeability transition triggers the release of apoptogenic factors, such as apoptosis inducing factor and cytochrome $c$, which in turn lead to later apoptotic events. ${ }^{20,21}$

We used the lipophilic cation 5,5',6,6'-tetrachlo-1,1',3,3'-tetraethylbenzimidazol-carbocyanine (JC-1) to monitor changes in $\Delta \psi_{\mathrm{mt}}$ induced by $\mathbf{4 b}$. The method is based on the ability of this fluorescent probe to enter selectively into the mitochondria, and its color changes reversibly from green to orange as membrane potential increases. ${ }^{22}$ This property is due to the reversible formation of JC-1 aggregates upon membrane polarization. Aggregation causes a shift in the emitted light from $530 \mathrm{~nm}$ (i.e., emission by JC-1 monomers) to $590 \mathrm{~nm}$ (emission by JC-1 aggregates) following excitation at $490 \mathrm{~nm}$.

HeLa cells were treated with compound $\mathbf{4 b}$ for 24,48 and $72 \mathrm{~h}$ at 0.5 and $1 \mu \mathrm{M}$. As shown in Figure 2, compound $\mathbf{4 b}$ induces substantial mitochondrial depolarization in a time- and concentrationdependent manner. The disruption of the $\Delta \psi_{\mathrm{mt}}$ is associated with the appearance of sub-G1 cells and with the marked increase in the percentage of annexin- $\mathrm{V}$ positive cells.

Mitochondrial membrane depolarization is associated with mitochondrial production of reactive oxygen species (ROS). ${ }^{23,24}$ ROS are highly reactive molecules with both free radical and non-radical structures, including superoxide anion, hydrogen peroxide, hydroxyl radical and single oxygen. ROS play a central role 
<smiles>O=Cc1ccc([N+](=O)[O-])cc1</smiles><smiles>C=C(Br)C(=O)Nc1cccc(/C=C/C(=O)/C=C/c2cccc(NC(=O)C(=C)Br)c2)c1</smiles><smiles>[X]CC(=Cc1cccc([N+](=O)[O-])c1)C(=O)C(C=Cc1ccc([R])cc1)=Cc1cccc([N+](=O)[O-])c1</smiles>

b<smiles></smiles>

6a, $\mathrm{R}=3-\mathrm{NH}_{2}$

6i, $\mathrm{R}=4-\mathrm{NH}_{2}$

6b, $\mathrm{X}=\mathrm{CH}_{2}$

6c, $\mathrm{X}=\mathrm{CH}\left(\mathrm{CH}_{3}\right)$

6d, $\mathrm{X}=\left(\mathrm{CH}_{2}\right)_{2}$

6e, $\mathrm{X}=\left(\mathrm{CH}_{2}\right)_{3}$

6f, $\mathrm{X}=\mathrm{NBn}$

$6 \mathrm{~g}, \mathrm{X}=\mathrm{NCO}_{2} \mathrm{CH}_{3}$

6h, $X=\mathrm{NCO}_{2} \mathrm{CH}_{2} \mathrm{CH}_{3}$

c<smiles>[X]CC(=Cc1cccc(NC(=O)C(=C)Br)c1)C(=O)C=Cc1cccc(NC(=O)C(=C)Br)c1</smiles>

4b, $\mathrm{X}=\mathrm{CH}_{2}$

4c, $\mathrm{X}=\mathrm{CH}\left(\mathrm{CH}_{3}\right)$

4d, $\mathrm{X}=\left(\mathrm{CH}_{2}\right)_{2}$

4e, $\mathrm{X}=\left(\mathrm{CH}_{2}\right)_{3}$

4f, $\mathrm{X}=\mathrm{NBn}$

4g, $\mathrm{X}=\mathrm{NCO}_{2} \mathrm{CH}_{3}$

$4 \mathrm{~h}, \mathrm{X}=\mathrm{NCO}_{2} \mathrm{CH}_{2} \mathrm{CH}_{3}$

Scheme 1. Reagents: (a) LiOH $\cdot \mathrm{H}_{2} \mathrm{O}$, cyclic/acyclic ketone, $m$-nitrobenzaldehyde for the synthesis of $\mathbf{5 a}-\mathbf{b}, p$-nitrobenzaldehyde for the synthesis of $\mathbf{5 i}$, EtOH, $\mathrm{rt}, 18 \mathrm{~h}$; (b) Fe, $\mathrm{NH}_{4} \mathrm{Cl}, \mathrm{H}_{2} \mathrm{O}$-EtOH, reflux, $2 \mathrm{~h}$; (c) $\alpha$-bromoacrylic acid, EDCI, HOBt, DMF, 18 h, rt.

Table 2

Cell-cycle distribution of HeLa cells after $24 \mathrm{~h}$ of treatment with compounds $\mathbf{4 b}, \mathbf{4 c}, \mathbf{4 e}$ or $\mathbf{4 g}$

\begin{tabular}{|c|c|c|c|c|c|}
\hline \multirow[t]{2}{*}{ Compound } & \multirow[t]{2}{*}{ Concentration $(\mu \mathrm{M})$} & \multicolumn{4}{|c|}{ Cell cycle percentage (\%) } \\
\hline & & Sub-G1 ${ }^{a}$ & $\mathrm{G} 1^{\mathrm{b}}$ & $S^{b}$ & $\mathrm{G} 2-\mathrm{M}^{\mathrm{b}}$ \\
\hline Control & NM & $1.9 \pm 0.3$ & $52.9 \pm 3.3$ & $29.0 \pm 3.0$ & $18.1 \pm 0.9$ \\
\hline $4 b$ & 0.25 & $4.7 \pm 2.1$ & $44.7 \pm 1.1$ & $35.8 \pm 4.0$ & $16.1 \pm 0.5$ \\
\hline $4 b$ & 1.0 & $27.2 \pm 1.2$ & $28.8 \pm 6.0$ & $22.7 \pm 7.1$ & $51.9 \pm 10.4$ \\
\hline $4 c$ & 0.25 & $3.2 \pm 0.6$ & $41.6 \pm 5.5$ & $43.5 \pm 0.8$ & $14.8 \pm 4.7$ \\
\hline $4 c$ & 0.5 & $4.0 \pm 1.1$ & $59.2 \pm 9.0$ & $16.1 \pm 2.6$ & $27.5 \pm 3.8$ \\
\hline $4 c$ & 1.0 & $4.5 \pm 0.9$ & $26.5 \pm 1.5$ & $31.3 \pm 6.5$ & $41.9 \pm 8.0$ \\
\hline $4 e$ & 1.0 & $15.6 \pm 7.5$ & $32.6 \pm 10.6$ & $12.9 \pm 2.5$ & $54.5 \pm 7.8$ \\
\hline $4 g$ & 0.25 & $8.0 \pm 3$ & $49.2 \pm 4.0$ & $36.8 \pm 6.8$ & $14.5 \pm 3.4$ \\
\hline $4 g$ & 0.5 & $7.2 \pm 1.0$ & $51.9 \pm 3.9$ & $34.6 \pm 11.7$ & $13.4 \pm 8.2$ \\
\hline $4 \mathrm{~g}$ & 1.0 & $8.2 \pm 2.1$ & $57.0 \pm 2.5$ & $17.5 \pm 2.0$ & $24.9 \pm 4.1$ \\
\hline
\end{tabular}

Data are expressed as the mean \pm SE from the dose-response curves of at least three independent experiments.

NM: not meaningful.

${ }^{a}$ Percentage of the cell population with hypodiploid DNA content peak (apoptotic cells).

b The percentage of cells in each phase of the cell cycle was calculated using living cells.

as second messengers in a number of signal transduction pathways and cause a wide range of cellular responses ranging from transient to permanent growth arrest, and from apoptosis to necrosis, dependingon the level of ROS.
To investigate the effects of $\mathbf{4 b}$ on the production of oxygen species during apoptosis, we utilized two fluorescence probes, hydroethidine (HE) and 2',7'-dichlorodihydrofluorescein diacetate $\left(\mathrm{H}_{2} \mathrm{DCFDA}\right)$. The fluorescence of these compounds occurs if ROS 


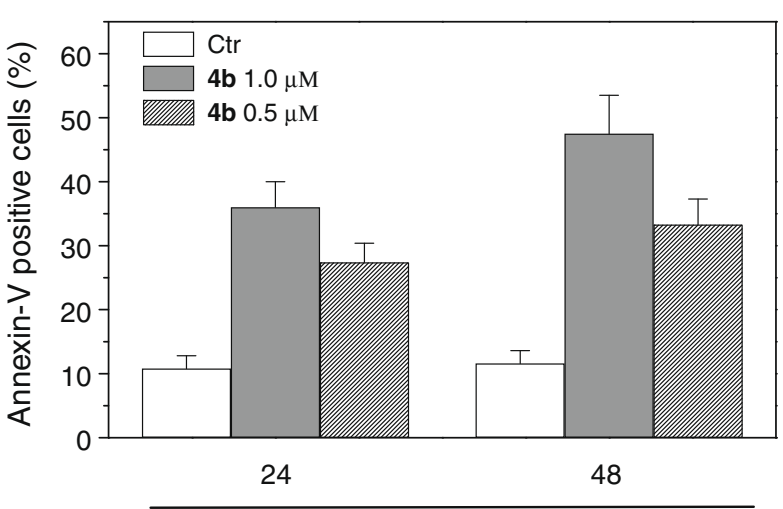

Time (h)

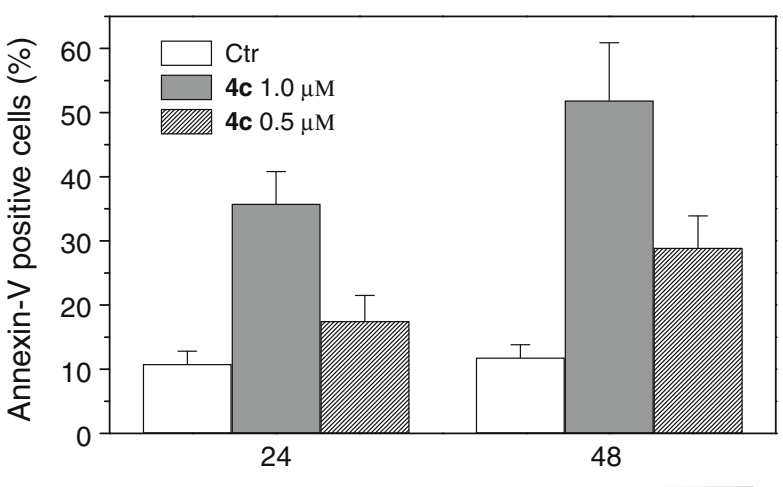

Time (h)

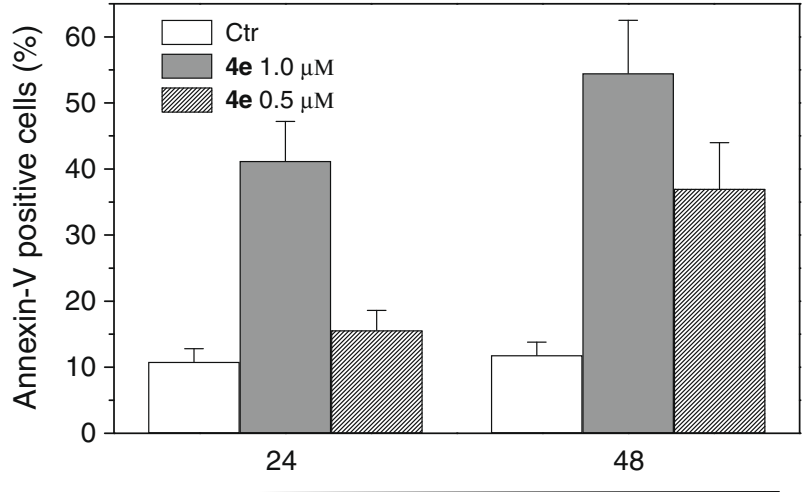

Time (h)

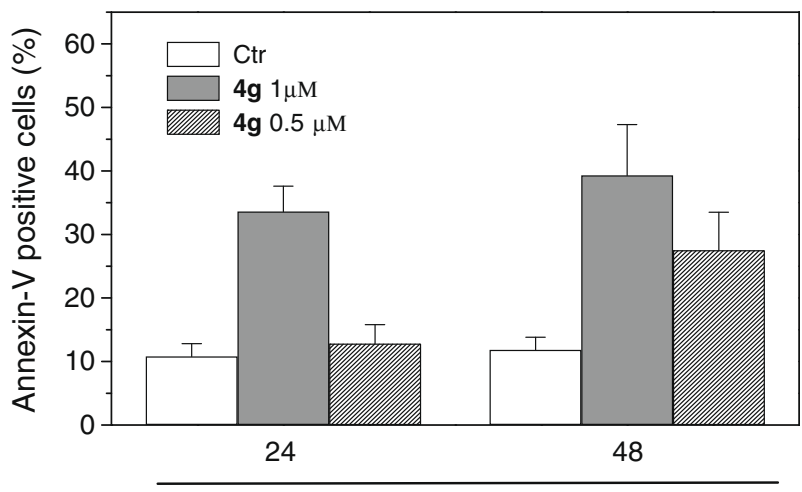

Time (h)

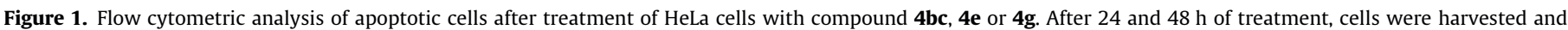

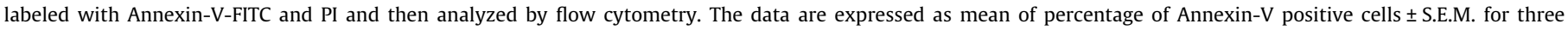
independent experiments.

are generated. ${ }^{25}$ As shown in Figure 3 (upper and medium panels), there was an increase in cells producing ROS that closely paralleled the increase in cells with low $\Delta \psi_{\mathrm{mt}}$, as a function of both the concentration of $\mathbf{4 b}$ and treatment time.

We also evaluated the damage caused by ROS in mitochondria by assessing the oxidation state of cardiolipin, a phospholipid restricted to the inner mitochondrial membrane. We used $10 \mathrm{~N}$-non$\mathrm{yl}$ acridine orange (NAO), a fluorescent probe which is independent

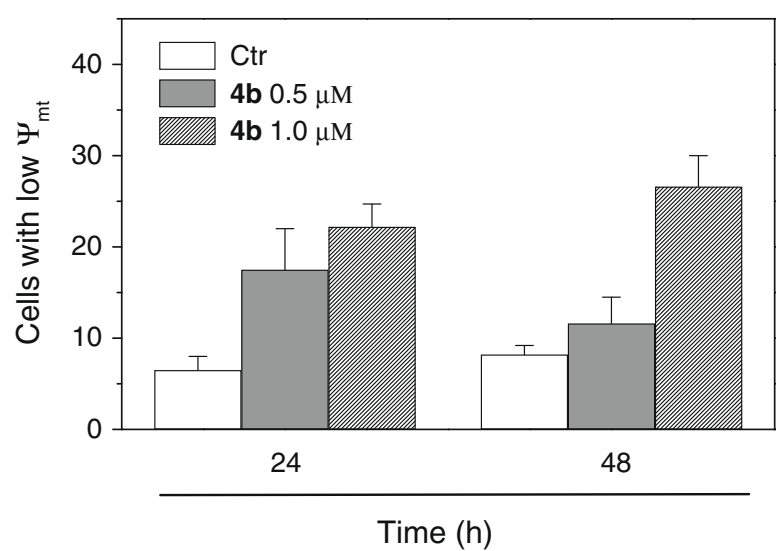

Figure 2. Assessment of mitochondrial potential after treatment with compound 4b. Upper panel: induction of loss of mitochondrial membrane potential after 24, 48 and $72 \mathrm{~h}$ of incubation of HeLa cells with $\mathbf{4 b}$ at 0.5 or $1.0 \mu \mathrm{M}$. Cells were stained with the fluorescent probe JC-1 and analyzed by flow cytometry. of the mitochondrial permeability transition. ${ }^{26}$ The dye interacts stoichiometrically with intact, non-oxidized cardiolipin. ${ }^{27}$ Somewhat unexpectedly, the cells did not show reduction in NAO fluorescence, but, rather, a marked increase in NAO, especially after $48 \mathrm{~h}$ of treatment with $\mathbf{4 b}$ (Fig. 3, lower panel). This effect suggests an increase in cardiolipin content as a consequence of increased mitochondrial mass. This has been recently observed by our group in $\mathrm{K} 562$ cells following treatment with hybrid $\alpha$-bromoacryloylamido chalcones ${ }^{15}$ but also in other tumor cell lines after treatment with herbimycin $\mathrm{A}^{28}$ genistein, ${ }^{29}$ and the acronicyne derivative S23906- $1^{30}$ and following oxidative stress. ${ }^{31}$

Altogether these results indicated that the cell cycle arrest and apoptosis induced by $\mathbf{4 b}$ in HeLa cells were correlated with a doseand time-dependent appearance of mitochondrial dysfunction.

The mechanism of apoptosis depends on a cascade of proteolytic enzymes called caspases. ${ }^{32}$ They exist in most cells as inactive precursors (zymogens) that, once activated sequentially, lead to irreversible cell death. Within the caspase family, caspase- 3 is essential for propagation of the apoptotic signal after exposure of cells to many DNA-damaging agents and other anticancer drugs. ${ }^{31,33}$ We therefore determined whether the activation of caspase- 3 was involved in the apoptosis induced by compound $\mathbf{4 b}$. We used a monoclonal antibody specific for the active fragment of caspase-3. As shown in Figure 4, with 0.5 and especially $1 \mu \mathrm{M} \mathbf{4 b}$ there was a marked activation of caspase- 3 after $24 \mathrm{~h}$ of treatment, and no further increase of caspase- 3 activity occurred after $48 \mathrm{~h}$.

In summary, our plan to optimize the potency of a double Michael acceptor by providing multiple sites of reactivity towards cellular nucleophiles led us to synthesize a series of bis-( $\alpha$-bromo- 


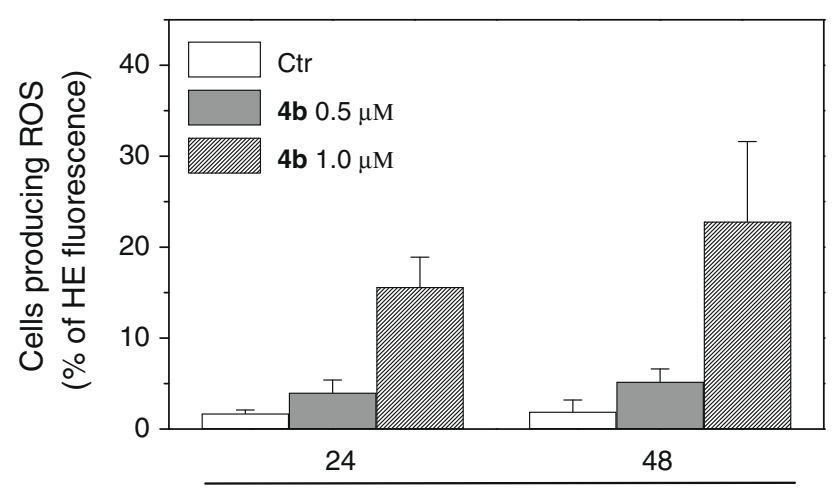

Time (h)

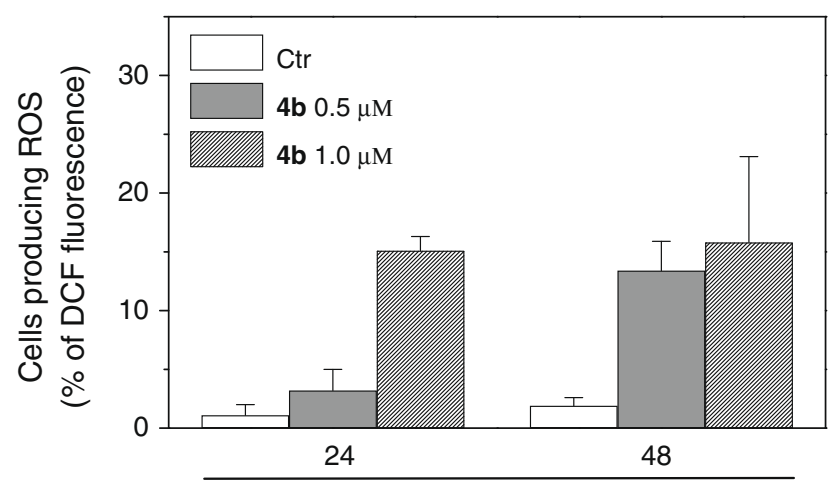

Time (h)

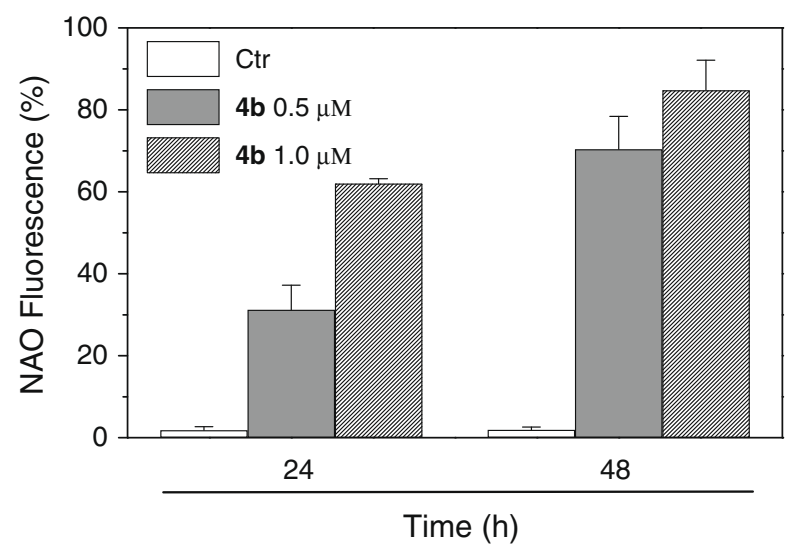

Figure 3. Mitochondrial production of ROS in HeLa cells. After 24 and $48 \mathrm{~h}$ of incubation with $\mathbf{4 b}$, cells were stained with $\mathrm{HE}$ (upper panel) or $\mathrm{H}_{2}$ DCFDA (middle panel) and analyzed by flow cytometry. Increase of mitochondrial mass in HeLa cells treated with compound $\mathbf{4 b}$ (lower panel). Cells were treated as above and the relative NAO intensity was analyzed by flow cytometry. The results are expressed as percentage of the fluorescence intensity with respect to untreated control cells. Data are expressed as mean \pm S.E.M. of three independent experiments.

acryloylamido benzylidene) ketones $\mathbf{4 a - h}$. Compared to melphalan, an established anticancer agent, derivatives $\mathbf{4 b - h}$ displayed significantly greater potency. These compounds were derived from the hybridization of two kinds of Michael acceptors, corresponding to the 1,5-diaryl-1,4-pentadien-3-one system of $\alpha, \alpha^{\prime}$-bis-(aminobenzylidene) ketones $\mathbf{6 a - i}$ and the $\alpha$-bromoacryloyl moiety. While compounds $\mathbf{6 a - i}$ showed weak or no antiproliferative activity against five cancer cell lines, the attachment of two $\alpha$-bromoacryloyl moieties led to significantly increased activity. The greater potency of hybrid compounds $\mathbf{4 a - h}$ than bis-(aminoarylidene) ketones $\mathbf{6 a - i}$ was attributed to the additional electrophilic groups

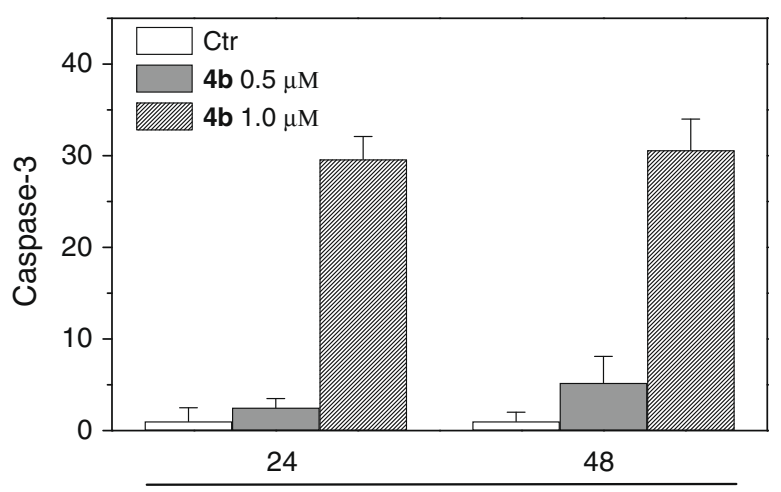

Time (h)

Figure 4. Caspase-3 induced activity by compound $\mathbf{4 b}$. HeLa cells were incubated in the presence of $\mathbf{4 b}$ at 0.5 or $1.0 \mu \mathrm{M}$. After 24 or $48 \mathrm{~h}$ of treatment, cells were harvested and stained with an anti-human active Caspase- 3 fragment monoclonal antibody conjugated with FITC. Data obtained by flow cytometric analysis are expressed as percentage of caspase- 3 active fragment positive cells. Data are expressed as mean \pm S.E.M. of three independent experiments.

in $\mathbf{4 a - h}$, enabling these compounds to act potentially as multifunctional Michael acceptors. In the series of cyclic ketones $\mathbf{4 b} \mathbf{b}-\mathbf{e}$, the six- and the eight-membered cyclic ring was preferred to the seven-membered ring. Compound $\mathbf{4 g}$ had no effect on cycle progression of HeLa cells even at higher concentrations, while compounds $\mathbf{4 b c}$ and $\mathbf{4 e}$ induced cell cycle arrest in a concentration-dependent manner. In particular, treatment with increasing concentrations of $\mathbf{4 b}$ led to cell cycle arrest in the G2-M phase accompanied by an increase in the percentage of apoptotic cells after 24 and $48 \mathrm{~h}$.

As demonstrated with $\mathbf{4 b}$, the mechanism of action of these compounds appears to be induction of apoptosis mediated by the activation of caspase- 3 and by important changes in mitochondrial function, such as dissipation of the transmembrane potential and generation of ROS. Further studies to clarify additional details of the molecular mechanism of action of these compounds and their selectivity in inhibiting the growth of cancer cells are underway.

\section{Acknowledgments}

Financial support was provided by GOA (Krediet No. 05/19) of the K.U. Leuven. The technical assistance of Mrs. Lizette van Berckelaer and Alberto Casolari is gratefully acknowledged.

\section{Supplementary data}

Supplementary data (detailed biological protocols, synthesis and spectroscopic data for hybrids $\mathbf{4 a - h}$ and $\mathbf{3 a b}$. General procedures for the synthesis of $\alpha, \alpha^{\prime}$-bis-(nitrobenzylidene) ketones 5a$\mathbf{i}$ and $\alpha, \alpha^{\prime}$-bis-(aminobenzylidene) ketones $\mathbf{6 a - i}$. Cell-cycle distribution of HeLa cells after $48 \mathrm{~h}$ of treatment with compounds $\mathbf{4 b}$, 4c, $4 \mathbf{e}$ and $\mathbf{4 g}$ (Table 1 )) associated with this article can be found, in the online version, at doi:10.1016/j.bmcl.2010.03.075.

\section{References and notes}

1. Ahn, B.-Z.; Sok, D.-E. Curr. Pharm. Des. 1996, 2, 247.

2. Dimmock, J. R.; Wong, M. L. C. Can. J. Pharm. Sci. 1976, 11, 35.

3. Lawrence, N. J.; McGown, A. T. Curr. Pharm. Des. 2005, 11, 1679.

4. (a) Das, U.; Sharma, R. K.; Dimmock, J. R. Curr. Med. Chem. 2009, 16, 2001; (b) Dimmock, J. R.; Elias, D. W.; Beazely, M. A.; Kandepu, N. M. Curr. Med. Chem. 1999, 6, 1125.

5. Dimmock, J. R.; Padmanilayam, M. P.; Zello, G. A.; Nienaber, K. H.; Allen, T. M.; Santos, C. L.; De Clercq, E.; Balzarini, J.; Manavathu, E. K.; Stables, J. P. Eur. J. Med. Chem. 2003, 38, 169.

6. Dimmock, J. R.; Das, U.; Gul, H. I.; Kawase, M.; Sakagami, H.; Barath, Z.; Ocsovsky, I.; Molnar, J. Bioorg. Med. Chem. Lett. 2005, 15, 1633. 
7. Das, U.; Gul, H. I.; Alcorn, J.; Shrivastav, A.; George, T.; Sharma, R. K.; Nienaber, K. H.; De Clercq, E.; Balzarini, J.; Kawase, M.; Kan, N.; Tanaka, T.; Tani, S.; Werbovetz, K. A.; Yakovich, A. J.; Manavathu, E. K.; Stables, J. P.; Dimmock, J. R. Eur. J. Med. Chem. 2006, 41, 577 .

8. Pati,H. N.; Das, U.; Sharma, R. K.; Dimmock, J. R. Mini-Rev. Med. Chem. 2007, 7, 131

9. Dimmock, J. R.; Padmanilayam, M. P.; Puthucode, R. N.; Nazarali, A. J. Motaganahalli, N. L.; Zello, G. A.; Quail, J. W.; Oloo, E. O.; Kraatz, H.-B.; Prisciak, J. S.; Allen, T. M.; Santos, C. L.; Balzarini, J.; De Clercq, E.; Manavathu, E. K. J. Med. Chem. 2001, 44, 586.

10. Baluja, G.; Municio, A. M.; Vega, S. Chem. Ind. 1964, 2053.

11. Mutus, B.; Wagner, J. D.; Talpas, C. J.; Dimmock, J. R.; Phillips, O. A.; Reid, R. S. Anal. Biochem. 1989, 177, 237.

12. Dimmock, J. R.; Raghavan, S. K.; Logan, B. M.; Bigham, G. E. Eur. J. Med. Chem. 1983, 18, 248.

13. (a) Lorusso, D.; Mainenti, S.; Pietragalla, A.; Ferrandina, G.; Foco, G.; Masciullo, V.; Scambia, G. Expert Opin. Invest. Drugs 2009, 18, 1939; (b) Leahy, M.; RayCoquard, I.; Verwei, J.; Le Cesne, A.; Duffaud, F.; Hogendoorn, P. C.; Fowst, C.; De Balincourt, C.; Di Paola, E. D.; Van Glabbeke, M.; Judson, I.; Blay, J. Y. Eur. J Cancer 2007, 43, 308.

14. Romagnoli, R.; Baraldi, P. G.; Cruz-Lopez, O.; Lopez-Cara, C.; Preti, D. Mini-Rev. Med. Chem. 2009, 9, 81.

15. Romagnoli, R.; Baraldi, P. G.; Carrion, M. D.; Cruz-Lopez, O.; Lopez Cara, C. Balzarini, J.; Hamel, E.; Canella, A.; Fabbri, E.; Gambari, R.; Basso, G.; Viola, G. Bioorg. Med. Chem. Lett. 2009, 19, 2022.

16. For the characterization of compounds $\mathbf{3 a}$ and $\mathbf{3 b}$, see Supplementary data.

17. Bhagat, S.; Sharma, R.; Chakraborti, A. K. J. Mol. Catal. A: Chem. 2006, 260, 235.
18. Vermes, I.; Haanen, C.; Steffens-Nakken, H.; Reutelingsperger, C. J. Immunol. Methods 1995, 184, 39.

19. (a) Hamel, E. Cell Biochem. Biophys. 2003, 38, 1; (b) Verdier-Pinard, P.; Lai, J.-Y.; Yoo, H.-D.; Yu, J.; Marquez, B.; Nagle, D. G.; Nambu, M.; White, J. D.; Falck, J. R.; Gerwick, W. H.; Day, B. W.; Hamel, E. Mol. Pharmacol. 1998, 53, 62.

20. Ly, J. D.; Grubb, D. R.; Lawen, A. Apoptosis 2003, 3, 115.

21. Green, D. R.; Kroemer, G. Science 2005, 305, 626.

22. Salvioli, S.; Ardizzoni, A.; Franceschi, C.; Cossarizza, A. FEBS Lett. 1997, 411, 77.

23. (a) Hancock, J. T.; Desikan, R.; Neil, S. J. Biochem. Sci. Trans. 2001, 29, 245; (b) Zamzami, N.; Marchetti, P.; Castedo, M.; Decaudin, D.; Macho, A.; Hirsch, T.; Susin, S. A.; Petit, P. X.; Mignotte, B.; Kroemer, G. J. Exp. Med. 1995, 182, 367.

24. (a) Nohl, H.; Gille, L.; Staniek, K. Biochem. Pharmacol. 2005, 6, 719; (b) Boonstra, J.; Post, J. A. Gene 2004, 337, 1.

25. Rothe, G.; Valet, G. J. Leukocyte Biol. 1990, 47, 440

26. Petit, J. M.; Maftah, A.; Ratinaud, M. H.; Julien, R. Eur. J. Biochem. 1992, 209, 267.

27. Gallet, P. F.; Maftah, A.; Petit, J. M.; Denis-Gay, M.; Julien, R. Eur. J. Biochem. 1995, 228, 113.

28. Mancini, M.; Anderson, B. O.; Caldwell, E.; Sedghinasab, M.; Paty, B. P.; Hockenbery, D. M. J. Cell Biol. 1997, 138, 449.

29. Pagliacci, M. C.; Spinozzi, F.; Migliorati, G.; Fumi, G.; Smacchia, M.; Grignani, F.; Riccardi, C.; Nicoletti, E. Eur. J. Cancer 1993, 29A, 1573.

30. Kluza, J.; Lansiaux, A.; Wattez, N.; Hildebrand, M. P.; Leonce, S.; Pierre, A.; Hickman, J. A.; Bailly, C. Biochem. Pharmacol. 2002, 63, 1443.

31. Lee, H. C.; Yin, P. H.; Lu, C. Y.; Chi, C. W.; Wei, Y. H. Biochem. J. 2000, 348, 425.

32. Kumar, S. Cell Death Differ. 2007, 14, 32.

33. Selvesen, S.; Dixit, V. M. Cell 1997, 91, 43. 